\title{
STUDIES ON MITES ASSOCIATED WITH SOME STORED HAY IN DIFFERENT REGIONS OF EGYPT
}

\author{
E.M.A. Yassin, Asmaa R. Abdel-Khalik, Safinaz A. Abdul-Aziz \\ and S.A. Osman \\ Plant Protection Research Institute, A.R.C., Dokki, Giza, Egypt
}

Received: Mar. 30, 2017

Accepted: Apr. 18, 2017

\begin{abstract}
The present study was conducted during two years (2015 and 2016) to throw light on the acari fauna of some common stored hay in different regions covered 7 Egyptian governorates differed in their ecological conditions. This study revealed the occurrence of 32 mite species differed in their feeding behavior infested different stored hay materials, belonging to 27 genera and 16 families under four suborders as follows: Suborder Astigmata which represented by 8 species belong to 7 genera and 3 families. The recorded families were Acaridae (5 species), Glycyphagidae (2 species) and Pyroglyphidae (one species). Also, suborder Prostigmata represented in this study by 14 mite species belonging to 12 genera in 7 families. The families were Cunaxidae (2 species), Eupodidae, Scutacaridae, Bdellidae and Tarsonemidae (one species for each), Cheyletidae (4 species) and Tydeidae (4 species). On the other hand, the mesostigmatid mites represented by 9 mite species belonging to 7 genera in 5 families were recorded. The dominant mite species was Proctolaelaps pygmaeus (Ascidae) and the most collected families were Ascidae and Laelapidae (3 species for each), while the cryptostigmatids have only one species in this study, Siculobata sicula (Berlese) belonging to Oribatidae. The most frequent and most dominant mites in this study were: Tyrophagus putrescentiae, Tarsonmeus graneries and Proctolaelaps pygmaeus as fungivorous mites; Caloglyphus berlesi and Acarus siro as grnaviorous mites; Pronematus rykei, Cheyletus eruditus, C. malaccensis and Blattisocius keegani as predators mainly on acarid mites and other microarthropds stored product pests. The study indicated that wheat and broad bean were the most stored hay containing mite species, 5 and 4 mites, respectively, but rice, soybean and barley hay were infested with only two mite species. On the other hand, the clover hay was contained three mite species. The study also showed that, Ashmoun region represented the highest number of mite species (32), while, El-Wahat El-Baharia and Kom Oshim regions were the lowest regions contained only (6) mite species.
\end{abstract}

Key words: Mites, survey, acari fauna, Astigmata, Prostigmata, Mesostigmata

\section{INTRODUCTION}

At present, feed shortage and its high cost are the major problems of animal protein sources deficiency for human in the developing countries, which are due to limited land resources and the high competition between human and livestock for high quality grains and protein supplements. Therefore, efforts have been made towards the solution of feed shortage by improving the conventional sources and investigating more unconventional feeds. Farmers in Egypt cultivate some field crops for using as human food such as wheat, broad bean, rice, clover as forage crop and soybean and barley as animal feed. Farmers dry these field crops as straw or hay during the time of need and during the storage periods. Crop residues (straw) and hay represent a potential source of dietary energy to ruminants if the protein content can be enriched. World wide lignocellulosic residue generation every day results in pollution of the environment and in loss of valuable materials that can be bioconverted to several added-value products (Howard et al., 2003). As these residues are renewable and in an abundant supply and they 
represent a potential solution to feeding animals in developing countries, Baker et al., (2014).The infestation of stored products by mites and other arthropods is usually associated with three types of damage (Stejskal 2001). Firstly, storage mites directly endanger human and animal health due to allergenic contamination of food (Olsson and Hage-Hamsten 2000). Secondly, mites are vectors of toxicogenic fungi and thus indirectly contribute to contamination of food and feed with mycotoxins (Hubert et al., 2004). Thirdly, mites cause significant grain weight losses and decreased germinability (Zdarkova and Reska 1976). It has been reported that they can also lead to human and animal acariasis such as acarodermatitis, intestinal acariasis, pulmonary acariasis and allergy ( $\mathrm{Li}$ and $\mathrm{Li}$ 1988). Mites associated with stored hay have different relationships, ranging from fungivorous, parasitic and predators associated with other microorganisms. According to the available literature numerous surveys of the stored product mites associated with different hay have been undertaken in various parts of the world, but only limited studies were carried out in Egypt. With due attention to the nutritional role of hay materials for domestic animals and birds, it is necessary to preserve the quality and the value of these materials by using modern methods and systems of management.Therefore, the present study was conducted to detect the mite species of some common stored hay in different regions of Egypt and to examine some aspects of their ecology and behavior during the two study years 2015 and 2016 .

\section{MATERIALS AND METHODS a- Survey study:}

Mite species associated with some of the stored hay (wheat, rice, broad bean, clover, soybean and barley) were surveyed in different governorates of Egypt, El-Menoufia (Ashmoun district), El-Qaluobia (Benha district), El-Dakahlia (Aga district), El-Behira (Rashid district), Giza (El-Wahat EL-Baharia district), El-Fayoum (Kom Oshim district) and Sohag (Sohag district). Samples (500 $\mathrm{gm}$ ) were randomized obtained from open fields, closed stores, stables and different animals stockades during different dates of study (January 2015-December 2016) and put in polyethylene bags, then transferred to laboratory for extraction and identification.

\section{b- Extraction and identification of mites:}

Mites extraction was carried out using modified Tullgren funnels. The collected mites were kept in Nesbitt's solution for about 24 hours for clearing them, Krantz and Walter (2009). Mites were examined microscopically and identified in Cotton and Field Crops Acarology Res. Dep., Plant Prot. Res. Inst., ARC. The identification of mounted sample occurred according to (Griffiths, 1960; Hughes 1976; Lindquist and Evans, 1965; Summers and Price, 1970; Karg, 1971; Zaher, 1986 and Krantz and Walter 2009).

\section{RESULTS AND DISCUSSION Survey of mite species associated with stored hay in different regions of Egypt:}

General survey on 7 Egyptian governorates was undertaken for two years 2015 and 2016. This study revealed the occurrence of 32 mite species infested different stored straw materials, belonging to 27 genera and 16 families under four suborders as follows, Table (1).

\section{1-Suborder: Acaridida (Astigmata):}

As shown in Table (1a), this suborder was represented by 8 different species belong to 7 genera and 3 families. The feeding habit of the collected mite species of this suborder is recorded, Table (1a). The recorded families were Acaridae (5 species), Glycyphagidae (2 species) and Pyroglyphidae (one species). The acarid mite, T. putrescentiae as observed from obtained data was found in all collected samples during all different investigation times with high population in most cases. On 
the other hand, the mite, $T$. longior was disappeared in this study from Benha, ElWahat El-Baharia, Kom Oshim and Sohag districts, but observed with few numbers in Ashmoun, Aga and Rashid districts associated with wheat hay in most cases. On the other hand, Caloglyphus berlesei was found with rare numbers associated with wheat and broad bean hay during the two study seasons in most regions but disappeared from Kom Oshim district. Also the bulb mite, Rhizoglyphus robini was recorded with rare numbers in Ashmoun, Benha, Aga and Rashid regions and disappeared from thee rest regions.

The glycyphagid mite, Glycyphagus ornatus recorded during this study associated with both wheat and broad bean hay in Ashmoun region and with wheat hay only at Rashid region with rare numbers. Also, Blomia tropicalus was recorded during August 2015 at Ashmoun region with one individual and disappeared from the rest regions during the study periods. The mite, Dermatophagoides farinae was recorded with rare numbers in Ashmoun and Rashid regions during 2015 only inhabiting wheat hay.

\section{2- Suborder Actinedida (Prostigmata):}

The tabulated data in Table (1b) showed that the prostigmatid mites inhabiting stored hay was represented by 14 mite species belonging to 12 genera in 7 families. The recorded families were Cunaxidae (2 species); Eupodidae, Scutacaridae, Bdellidae and Tarsonemidae (one species for each); Cheyletidae (4 species) and Tydeidae (4 species). Results of the current study revealed the presence of $C$. eruditus in five regions during study but it was not detected in both Aga and El-Wahat ElBaharia regions. However, the mite, Scutacarus pigrus (Scutacaridae) was the lowest abundant mite in this study, as, it recorded associated with clover hay only with rare numbers. In the present study, there were mites appeared in one season and disappeared during the other season, i.e. Pulaeus zaheri, Eupodes aegyptiacus, Scutacarus pigrus, Hemicheyletia bakeri and Orthotydeus kochi.

\section{3- Suborder Gamasida (Mesostigmata): \\ The tabulated data in Table (1c)} indicated that nine mite species belonging to 7 genera in 5 families of gamasid mites were recorded. The dominant species was the fungivorous mite, Proctolaelaps pygmaeus (Ascidae) and the most collected families were Ascidae and Laelapidae (3 species for each).The preadocus mite, B.keegani, and Hypoaspis freemani were collected during 2015 and disappeared 2016, while the fungivorous mite, Kleemenia plumosus (Ameroseiidae) found during 2016 inhabiting wheat, broadbean and rice hay, and not recorded during the first season.

\section{4- Suborder Oribatida (Cryptostigmata):}

Only one oribatid species surveyed in this study, Siculobata sicula and according to Zaher, 1986, this mite is prefer to feed on fungi, Table (1c).

The most frequent and most dominant mite in this study as all, were $T$. putrescentiae, $T$. graneries and $P$. pygmaeus as fungivorous mites; $C$. berlesi and $A$. siro as granivorous mites; $P$. rykei, $C$. eruditus and $C$. malaccensis and Blattisocius keegani as predacious mites preys mainly on acarid mites and other microarthropds stored product pests, Zaher, 1986. Among dominant and frequent mite species, $T$. granarius and $T$. putrescentiae are known to be mycophagous and their occurrence is might be correlated with the presence of seed-borne fungi (White and Sinha, 1979). Also, A. siro can be found as consumer of seed-borne fungi (Hubert et al., 2004).

The tabulated data in Table (2) indicated that the wheat and broad bean were the most stored hay containing the different mite 
species (the dominant species), 5 and 4 mites, respectively, but the stored rice, soybean and barley hay infested with two mite species only. On the other hand, the clover hay was included three mite species in this study.

Table (3) show the mite species numbers and abundance ratios in different study regions, where, Ashmoun region represented the highest harbored number and abundance ratio (32) mite species, and the most abundant species were, $T$. putrescentiae, A. siro, C. eruditus, p. rykei and T. graneries; while, EI-Wahat El-Baharia and Kom Oshim regions were the lowest regions (6) mite species only. This survey study emphasizes the important of mites on stored hay, information that may aid in understanding and preventing economic losses caused by mite contamination of these stored agricultural products. In Egypt, El-Adawy et al., (2000) found twenty mite families inhabiting hay at Ismailia Governorate distributed as 4 families of suborder Gamasida, 13 families in Actinedida, two families in Actinedida and one family in Oribatida.They observed that the most frequent families found in all tested regions were Tydeidae and Oribatidae.

Stored broadbean seemed to be more vulnerable to mite attack than other hay, as we consistently found more infested samples, more species and higher mean and median mite abundance per sample. Penzes et al., (2000) found T. longior migrate in large numbers from the straw serving as artificial soil for growing to the layer of soil that covers it, then climbing up on the stem of cucumber and reached the leaves and caused yellow spots appearing first on the adaxial surface of the older leaves, then gradually on young ones as well. The number of mites in stored grain, straw and hay related to the age of the substrate was demonstrated by Hallas et al., (1991). The authors also found that hay contained the highest number of storage mites but the major species in all 3 kinds of substrate were the same. The relative abundance of the species varied with the age of the substrate. The youngest substrates were dominated by Lepidoglyphus destructor and $T$. longior. Later $A$. siro, $C$ eruditus and Tarsonemus sp. (undescribed) occurred. Latest in the succession was Tydeus spp. Li et al., (2015) surveyed the following mites from wheat straw, A. siro, T. longior, Tyrolichus casei, Acarus siro, Euroglyphus maynei and Dermatophagoides farinae. Ardeshir et al., (2008) In Iran carried out a faunistic study on mites and their abundance in stored wheat, straw and dust in silos, flour-mills and mills. The mites Aleuroglyphus ovatus (Troupeau), Tyrolichus casei (Oudemans), Acarophenax tribolii (Newstead and Duvall), C. eruditus and Erythraeus garmsaricus Saboori et al., are newly recorded from wheat stores. The most abundant predator and pest were Acaropsellina sollers (Kuzin) and A. siro, respectively. In Demnark, Iversen et al., (1990) reported that $L$. destructor and $A$. siro were the predominant mites in grain, straw, and hay samples. Further studies are needed in Egypt, to understand the differences in mite populations in the stored hay as animal food so that better management can be put to prevent and control mite infestations. 
Studies on mites associated with some stored hay in different regions .......

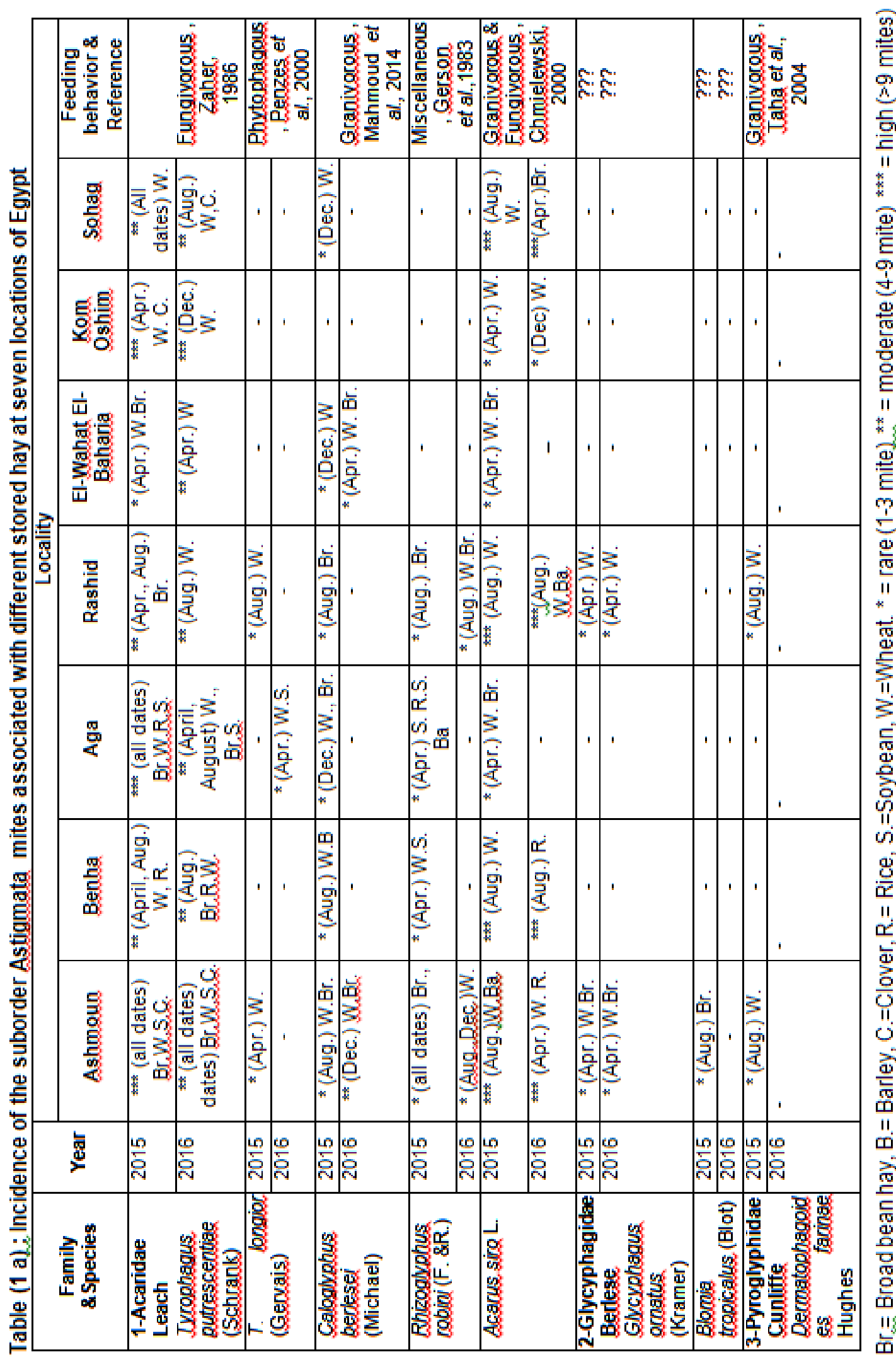


Yassin, et al.,

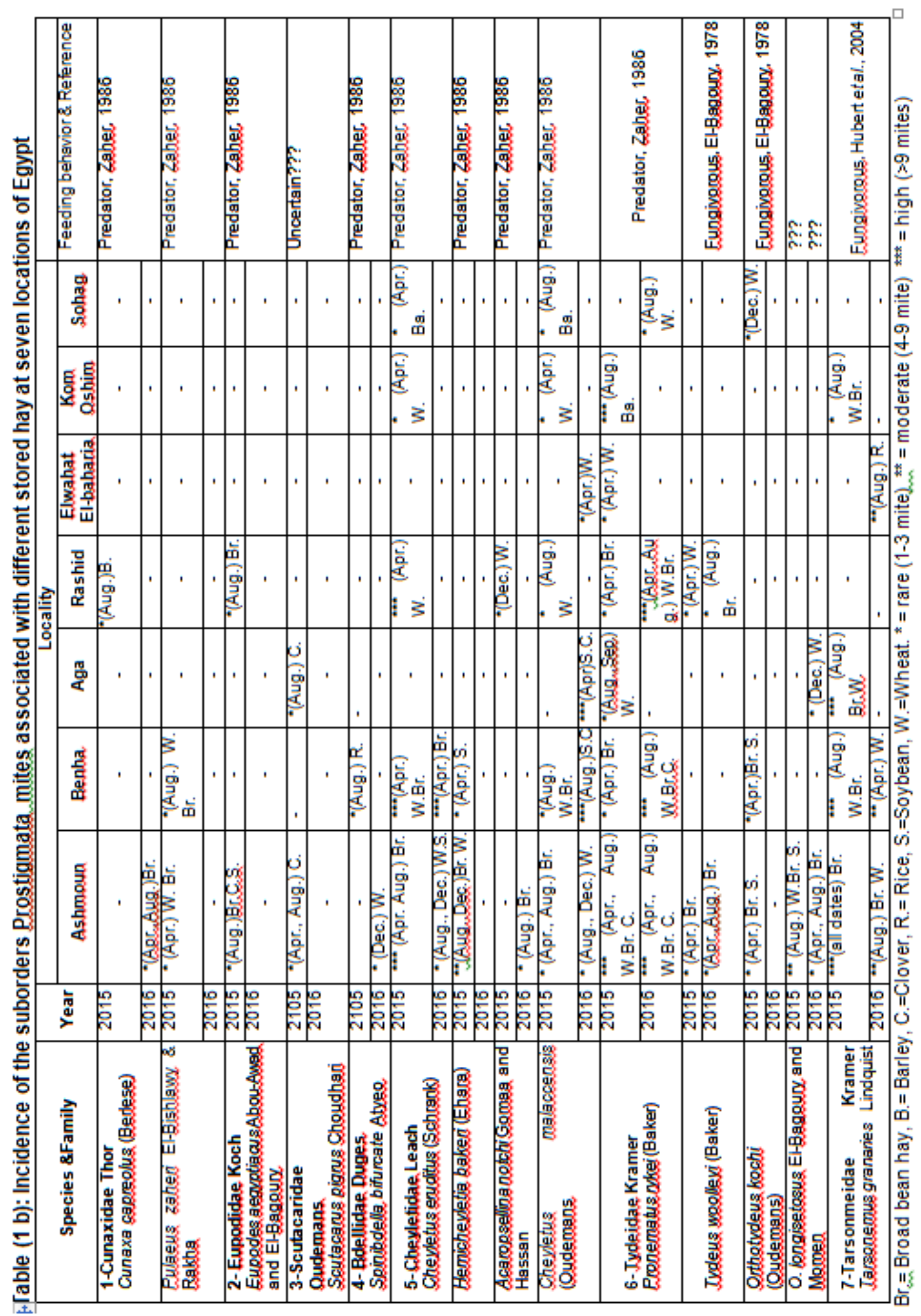


Studies on mites associated with some stored hay in different regions .......

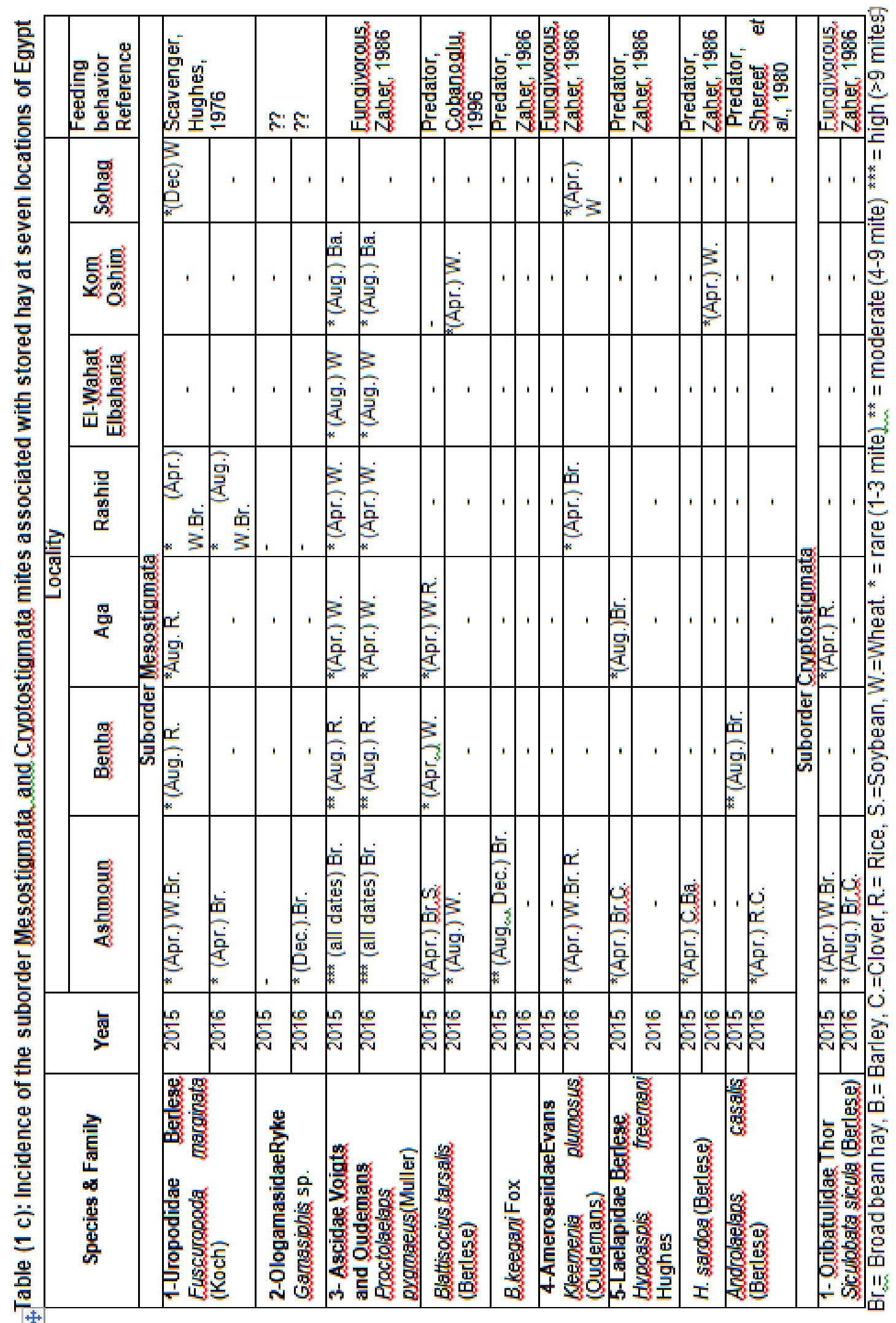


Yassin, et al.,
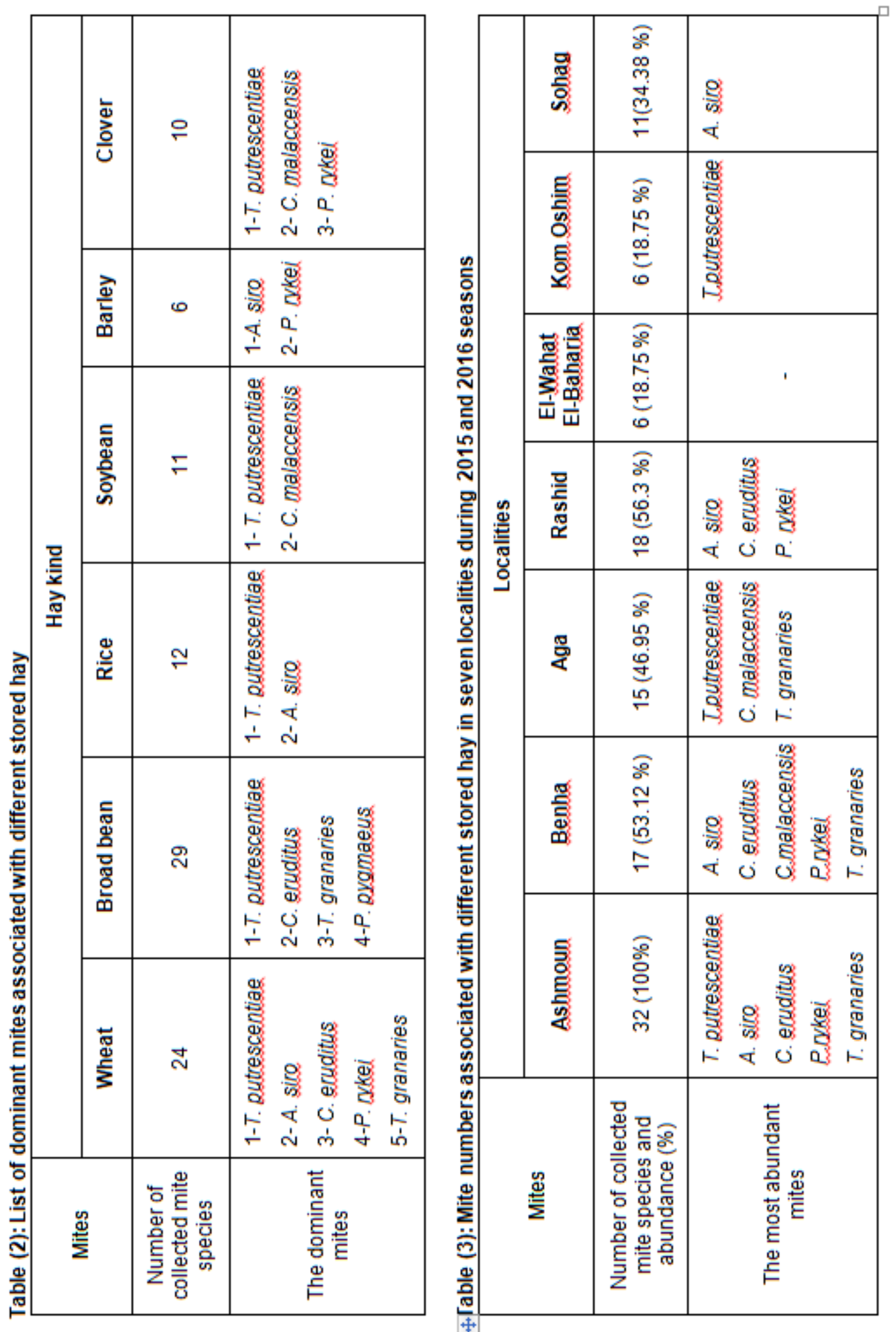


\section{REFERENCES}

Ardeshir, F., Y. Porshokouh and S. A. Reza (2008). A faunistic study and population fluctuation of mites associated with stored wheat in Tehran region, Iran. J. of Entomol. Soc. of Iran (JESI) 27, (2):17 28.

Baker, A. A., G.A. Darwish and M. S. M. Hasanin (2014). Improving the nutritive values of wheat straw and artichoke petals and their combinations by fungal treatments. J. Animal and Poultry Prod., Mansoura Univ., 5 (12): 725 - 735.

Chmielewski, W. (2000). Life history parameters of Acarus siro L. (Acari: Acaridae) fed buckwheat. Fagopyrum 17: 73-75.

Çobanoglu, S. (1996). Determination, distribution and habitat of Acarina group harmful and useful on stored products in the province of Edirne (Turkey).Turkish Journal of Entomology, 20 (3): 199-210.

El-Adawy, A.M., M.E. El-Sayes and T.A. ElSharkawy (2000). Mites infesting hay in Ismailia Governorate, Egypt. Egypt. J.Agric. Res., 76 (5): 1889-1895.

El-Bagoury, M. E. (1978). Ecological and biological studies on mites of family Tydeidae. Ph.D. Thesis, Fac. Agric., Cairo Univ., $111 \mathrm{pp}$.

Gerson, U., S. Capua and D. Thorens (1983). Life history and life tables of Rhizoglyphus robini Claparede (Acari: Astigmata: Acaridae). Acarologia, XXIV, 4: 439-448.

Griffiths, D. A. (1960). Some field habitats of mites of stored food products. Ann. Appl. Biol.; 48(1): 134-144.

Hallas, T. E., M. Iversen, J. Korsgaard and R. Dahl (1991). Number of mites in stored grain, straw and hay related to the age of the substrate (Acari). Entomologiske Meddelelser, 59: 57-60.

Howard, R.L., E. Abotsi, Jansen Van Rensburg, E.L. and S. Howard (2003). Lignocellulose biotechnology: Issues of bioconversion and enzyme production. Afr J. Biotechnol. 2: 602-619.
Hubert, J., V. Stejskal, A. Kubatova, Z. Munzbergova, M. Vanova and $E$. Zdarkova (2004). Mites and fungi in heavily infested stores in the Czech Republic. Journal of Economic Entomology, 97: 2144-2153.

Hughes, A. M. (1976). The mites of stored food products and houses. Tech. Bull., Min. Agric. and Fisheries in London, 63: $105-110$.

Iversen, M., J. Korsgaard, T. Hallas and R. Dahl (1990). Mite allergy and exposure to storage mites and house dust mites in farmers.Clin Exp. Allergy .20:211-219.

Karg, W. (1971). Die freilebenden Gamasina (Gamasides), Raubmilben. Die Tier welt Deutschlands 59: 475pp.

Krantz, G.W. and D.E. Walter (2009). A Manual of Acarology. Texas Tech Univ. Press, $807 \mathrm{pp}$.

Li, L.S. and Y.R. Li (1988). Acarology. Chongquing Publishing House, Chongqing, China, 520 pp.

Li, C., X. Zhan, E. Sun, J. Zhao, H. Wang, J. $\mathrm{He}$ and J. Wang (2015). The density and species of mite breeding in the stored products in China. Nutr. Hosp.; 31(2):798-807.

Lindquist, E.E. and G.O. Evans (1965). Taxonomic concepts in the Ascidae, with a modified setal nomenclature for the idiosoma of the Gamasina (Acarina: Mesostigmata). Mem. Ent. Soc. Can., 47: 1-64.

Mahmoud, H., H. A. Abd El-Wahab, H.A. Azzouz and H.A. Riham (2014). Effect of different types of food and temperatures on developmental stages, fecundity and life table parameters of the acarid mite, Caloglyphus berlesi (Michael) (Acari: Acaridida: Acaridae). J. Plant Prot. And path., Mansoura Univ., 5 (12): 12011208.

Olsson, S. and M. Hage-Hamsten (2000). Allergens from house dust and storage mites: similarities and differences, with emphasis on the storage mite Lepidoglyphus destructor.Clinical and Experimental Allergy, 30: 912-919. 
Penzes, B., J. Fail and T. Acs (2000). The damage of Tyrophagus longior Gervais on forced cucumber. Lippay Janos and Vas Karoly Tudomanyos Ulesszak, Novemebr, 6-7, Novenyvedelmi Szekcio.

Shereef, G.M., Z. R. Soliman and A.M. Afif (1980). Biology and economic importance of the mite Hypoaspis sardoa (Mesostigmata: Laelapidae). Zoological Society of Egypt Bulletin (30): 109-114

Stejskal, V. (2001). A new concept of economic injury level that includes penalization of damage to quality and safety of agricultural products.Plant Protection Science, 37: 151-156.

Summers, P. M. and D.W. Price (1970). Review of the mite family Cheyletidae. Univ. Calif. Publ. Entomol., 61: 153 p

Taha. H.A., S. K. Abou El-Ela and M.A. ElSanady (2004). Effect of food and temperature on developmental stages and fecundity of the grain mite, Dermatophagoides farinae Hughes
(Acari: Pyroglyphidae).Egypt. J. Agric. Res., 82 (3): 1121-1126.

White, N.D.G. and R.N. Sinha (1979).

Natural regulation of Tarsonemus granarius numbers in stored wheat ecosystems-A multivariate assessment. Recent Adv. In Acarol. (ed. J.G. Rodriguez) 1:291-298. Academic Press, New York.

Zaher, M. A. (1986). Survey and ecological studies on phytophagous, predaceous and soil mites in Egypt. II- Predaceous and non-phytophagous mites (Nile valley and Delta). PL-480 Program. USA Project No. EG- ARS-30. Grant No. FGEG-139, 567 pp.

Zdarkova, E. and M. Reska (1976). Weight losses of groundnuts (Arachis hypogaea L.) from infestation by the mites Acarus siro L. and Tyrophagus putrescentiae (Schrank). J. of St. Prod. Res, 12: 101104. 
دراسات على الاكاروسات المرتبطة بالتبن المخزن فى مناطق مختلفة من مصر

\section{عصام محمد عبدالسلام ياسين ، اسماء رضا عبدالخالق ، صافيناز احمد عبدالعزيز ، صدقى عبدالحميد عثمان}

معهد بحوث وقاية النباتات - مركز البحوث الزراعية - الدقى - جيزة مصر

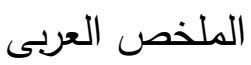

أجريت هذه الدراسة على مدار عامين (2015 ، 2016) لالقاء بعض الضوء على البيئة الاكاروسية فى التبن

المخزن فى 7 محافظات من مصر ومختلفة فى طبيعتها البيئية وهى (المنوفية - القليوبية - الدقهلية - البحيرة -

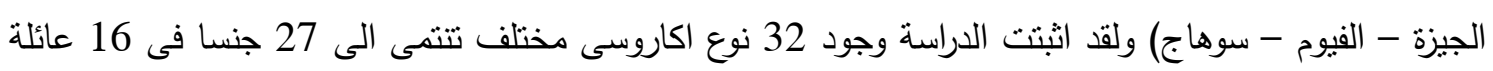
و اربعة تحت رثب اكاروسية كالاتى:- تحت رثبة عديمة الثغر

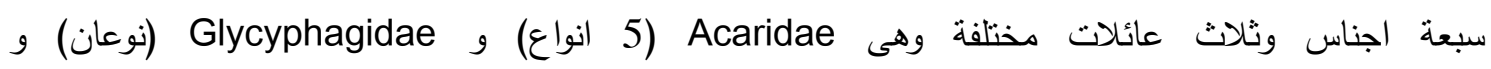

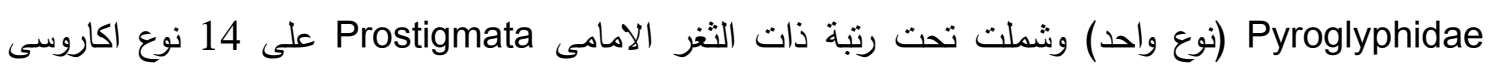

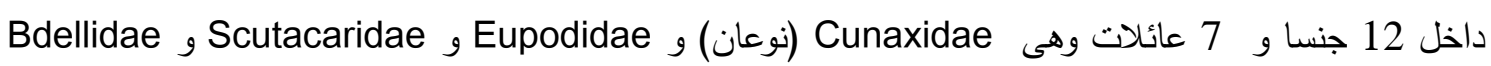
و Tarsonemidae (نوع واحد لكل عائلة) و Cheyletidae (4 انواع) و Tydeidae (4 انوعان). ولقدان منلت الاكاروسات المنتمية لتحت رثبة ذات الثغر المنوسط Mesostigmata في هذه الدراسة ب واحت 9 انواع و 7 اجناس داخل 5 عائلات اكاروسية. وكان اكثر الانواع شيوعا هو النوع Proctolaelaps pygmaeus الفطرى التغذية

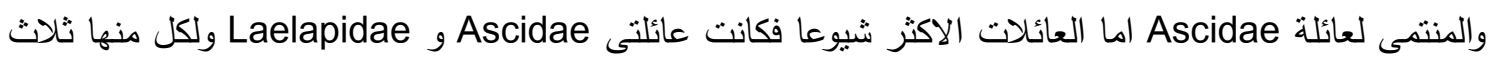

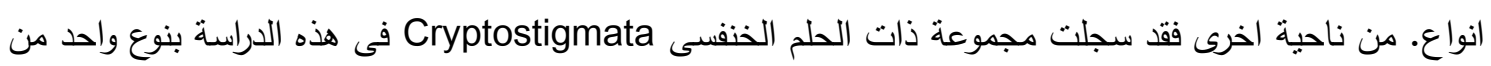

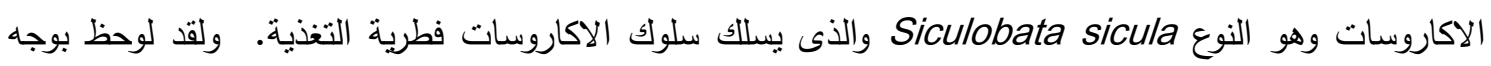
عام ان الاكاروسات P. pygmaeus و T. graneries , T. putrescentiae هى اكثر الاتواع الفطرية

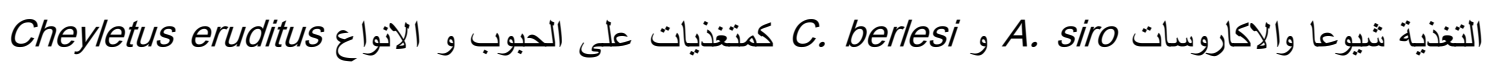

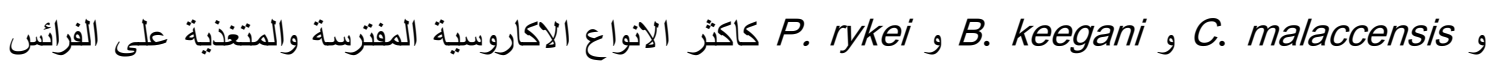

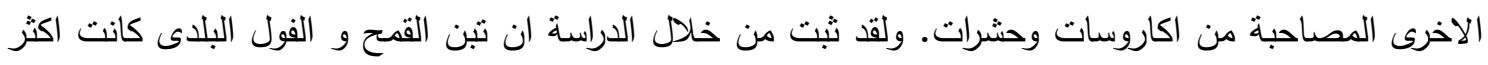

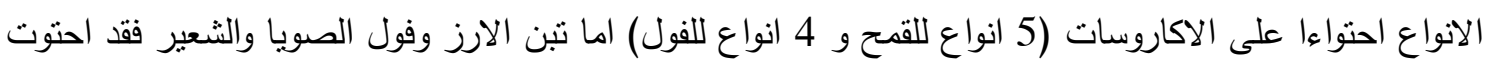

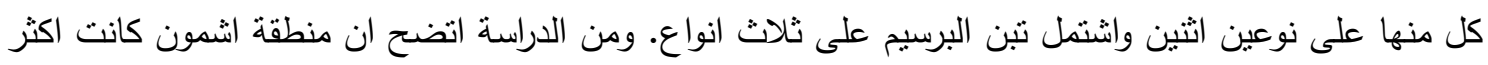

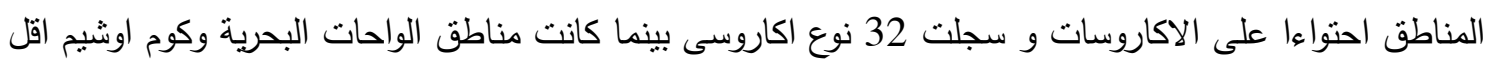
المناطق احتواءا على الاكاروسات (6) انواع لكل منهاء. 
Menoufia J. Plant Prot., Vol. 2 June (2017): 191 - 201 